\title{
Effect of Water-Soluble Fraction of Petroleum Hydrocarbon on the Growth and Sporulation of Botryodiplodia theobromae (Pat.)
}

\author{
John Meomikem Ehiobu \\ Department of Biology, College of Education, Agbor, Nigeria
}

Email address:

meomikem@yahoo.co.uk

\section{To cite this article:}

John Meomikem Ehiobu. Effect of Water-Soluble Fraction of Petroleum Hydrocarbon on the Growth and Sporulation of Botryodiplodia theobromae (Pat.). Journal of Diseases and Medicinal Plants. Vol. 3, No. 5, 2017, pp. 83-87. doi: 10.11648/j.jdmp.20170305.11

Received: October 10, 2017; Accepted: October 28, 2017; Published: November 20, 2017

\begin{abstract}
The control of fungal pathogens of economic crops in soil is crucial to sustainable food production and distribution. In this study, the effect of aqueous fractions of petroleum hydrocarbons was investigated on the growth and sporulation of Botryodiplodia theobromae (Pat.), a common fungal pathogen isolated from rotten cassava tubers. The fungal isolates were subjected to graded concentrations of the water-soluble fraction (WSF) of crude oil and monitored for their effects on the mycelial growth and spore germination using standard mycological media and techniques. Results revealed that the biological effects of the chemical fraction were concentration dependent and significant at $\mathrm{P}=0.01$ and 0.05 when compared with the controls. After $5 \mathrm{~h}$, the least inhibitory effect against the spore germination was observed by the $1 \mathrm{~mL}$ WSF concentration with $87 \%$ spore germination. The effects were significantly different $(\mathrm{P}<0.01)$ at WSF concentrations of 7.0-9.0 $\mathrm{mg} / \mathrm{mL}$ with percentage germination values of $44 \%, 46 \%$ and $29 \%$ respectively. The mycelial growths were also significantly reduced with the highest inhibition being $73 \%$ at $9.0 \mathrm{mg} / \mathrm{mL}$. The mycelial dry weight remained significantly unchanged $(\mathrm{P}>0.05)$ at higher concentrations. Findings from this study suggest that aqueous soluble fractions of petroleum hydrocarbons can significantly inhibit the spores and mycelium growth of $B$. theobromae (Pat.). Thus, they could be exploited as template for biosynthesis of potential fungicide against the test phytopathogens.
\end{abstract}

Keywords: Fungicide, Botryodiplodia theobromae (Pat.), Hydrocarbon, Water

\section{Introduction}

Botryodiplodia theobromae (Pat.) (Griff. and Maubl.), is a common soil-borne fungal pathogen with the sexual and asexual stages respectively referred to as known as Physalospora rhodina (Berk. \& Curt. apud Cooke) and Botryosphaeria rhodina (Berk and M.A. Curtis) [1, 2]. It is a ubiquitous fungus of a wide range of tropical and subtropical plants. A list of host of this pathogen is endless with over 500 plant species reported to have experienced diverse pathological disorders from the pathogen [2]. In the tropics, most of the crops reportedly attacked and reduced economically by these pathogens include various tubers crops, fruits and vegetables. The crops mostly attacked by the spores of $B$. theobromae (Pat.) are those with mechanical injury or weakened structural and physiological defenses, thereby making them important opportunistic pathogens of plants. They have been reported to cause die-back pod rot of cocoa, stem end rot of banana fruits, stem end rot of mango, stem end rot of pawpaw, leaf spot rot of citrus, collar rot of peanuts, storage rot of cassava, storage rot of potatoes and tuber rots of yams [2-5]

Over the years, the rots symptoms of pathogens have been managed via conventional cultural control practices and use of fungicides. Chemical fungicides have remained one of the widely used agents for management of post harvest rot diseases of crops because of their quick interventions and efficacies. The major drawback with some of the chemicals agents, such as Benomyl, is the issue of chemical residues among others. To address the issues, researchers, have advocated the exploration of organic and inorganic fungicides with reduced risks and environmental degradation 
[6]. Hydrocarbons from petroleum products have been exploited over the years as raw materials for production of agrochemicals and fertilizers. Considering the availability of such hydrocarbon raw materials in the environment, its water-soluble fraction was, therefore, investigated to determine their in vitro effects on $B$. theobromae spores germination, with a view to sourcing novel antifungal template from the hydrocarbon compounds.

\section{Materials and Methods}

\subsection{Sample Collection}

The cassava tubers, used for the isolation of the test fungus, were collected from Uselu Market in Benin City, Edo State, Nigeria. The crude oil used in this study was obtained with permission from Odidi oil field of Shell Petroleum Development Company, Warri, Delta State.

\subsection{Isolation of Pure Culture of Botryodiplodia theobromae}

Two of the collected tubers of cassava (approximately 40 $\mathrm{cm}$ long) were sliced into 2 equal halves to obtain 4 halves. Each of the sliced surfaces was exposed for 2 days in the plant house. After 2 days exposure, the exposed sliced surfaces were moistened with tap water and covered with transparent polythene sheet. Moistening of the sliced surfaces of cassava tubers was done at 2 days interval for 10 days. On the $11^{\text {th }}$ day, the exposed sliced surfaces were taken to the laboratory for mycological study. Inoculum was collected from the sliced cassava tubers and plated on the sterile Potato Dextrose Agar (Oxoid) plates using spreading plated techniques. The cultured plates were incubated at room temperature for 5 days. The blue-black coloured mycelia were purified and identified as Botryodiplodia theobromae (Pat.) using standard reference mycology atlas [7]. A pathogenicity test was also carried out on the fungi using fresh sterilized cassava tubers.

\subsection{Preparation of Water Soluble Fractions of Crude Oil}

Water-soluble fractions of crude oil were obtained by mixing $250 \mathrm{~mL}$ of the crude oil with 250 of distilled water in $1 \mathrm{~L}$ conical flask. The mixture was shaken thoroughly to enable the soluble fractions of the crude oil to dissolve in distilled water. The insoluble factions were decanted and separated. The working concentrations used were prepared and included $1.0 \mathrm{mg} / \mathrm{mL}-9.0 \mathrm{mg} / \mathrm{mL}$

\subsection{Preparation of Spore Suspension of B. theobromae}

Pycnidia were harvested from 8 day old pure culture of $B$. theobromae, and suspended into a $50 \mathrm{~mL}$ beaker containing distilled water. An inoculating needle was used to tease the spores out of the pycnidia into the distilled water. The resulting spore suspension was filtered through cotton wool. A drop of the filtrate was placed on a sterilized glass slides, covered with a flame-sterilized cover slip and examined under a microscope to confirm the presence of spores.

\subsection{Effect of Water-Soluble Fraction of Crude Oil on Germination of the Spores of B. theobromae in a Liquid Medium}

Varied concentration $(1.0-9.0 \mathrm{mg} / \mathrm{mL})$ of water soluble fractions of crude oil was introduced to 9 different sterile 15 $\mathrm{mm}$ diameters Petri dishes. A tenth plate without water soluble fractions served as control. A drop the spore suspensions (diluted to $10^{4}$ suspensions) was added in each Petri dish before incubation at room temperature. Two drops of about $0.2 \mathrm{~mL}$ was mounted on a microscope slide and covered with cover slip. Observations were made under the microscope at hourly interval. Numbers of germinating spores were counted from each observed slide. Percentage germination was calculated using the following formula:

$$
\text { Spore germination }=\frac{\text { Number of germinated spores }}{\text { Total Number of spores in a slide }} \times 100
$$

\subsection{Effect of WSF of Crude Oil Dry Weight of B. Theobromae Mycelium}

About $100 \mathrm{~mL}$ of nutrient broth was measured into separate $200 \mathrm{~mL}$ conical flasks and sterile using autoclave at $121^{\circ} \mathrm{C}$ for $15 \mathrm{~min}$. From the margin of the actively growing 5 day old culture of the test pathogen, a $6 \mathrm{~mm}$ diameter mycelia disc was removed aseptically using a cock borer and added to the broth. Thereafter, the graded concentrations $(1.0-9.0 \mathrm{mg} / \mathrm{mL})$ of water-soluble fractions of crude oil were added into the nutrient broth-mycelial mixture in the flasks. All the flasks were incubated at $30^{\circ} \mathrm{C}$ for 10 days before using a pre-weighed $15 \mathrm{~mm}$ diameter Whatman No. 1 filter paper to filter the flask content. The residue and filter papers were then dried to a constant weight using an oven set at $80^{\circ} \mathrm{C}$ and reweighed. The weight difference was taken as the mycelial dry weight of the test fungi [8].

\subsection{Effect of WSF of Crude Oil on the Mycelial Growth of B. theobromae}

Freshly prepared PDA plates were aseptically sprayed with $1-9 \mathrm{mg} / \mathrm{mL}$ of the WSF of crude oil before inoculating $6 \mathrm{~mm}$ mycelial disc of a 5 day old culture of $B$. theobromae onto each plate. Controls were set up without adding the WSF of the oil. The effect of the chemical fractions on the growth of the test fungi was monitored at intervals of two days for 10days, by measuring the mycelial diameter. The percentage growth inhibition was determined using the formula below

$$
\% \text { Growth inhibition }=\frac{\text { DiamterofControl-Diameteroftreatment }}{\text { DiameterofControl }} \times 100(2)
$$

\subsection{Statistical Analysis}

The replicate experimental data were analyzed for variance significant means were separated using $\mathrm{SAS}$ at $\mathrm{P}=0.01$ and 0.05 [9] 


\section{Results and Discussion}

The water-soluble fraction of petroleum hydrocarbon refers to the faction of hydrocarbon that dissolved partially or completely in aqueous solution. Such portion can readily penetrate and distort the cellular activities of organisms exposed to it [10]. In this study, the effect of aqueous soluble fraction of petroleum hydrocarbon on the spore germination and mycelial growthof $B$. theobromae was investigated with a view to sourcing for a novel antifungal template for selective control of fungal pathogens. The results as shown in Table 1 revealed that WSF of petroleum hydrocarbon possess inhibitory activities against the test pathogen. The effect was concentration dependent and significant at $\mathrm{P}=0.01$ and 0.05 when compared with the controls. After $5 \mathrm{~h}$, the least inhibitory effect against the spore germination was observed from the $1.0 \mathrm{~mL}$ WSF concentration with $87 \%$ spore germination. The effect was not significantly different
$(\mathrm{P}<0.05)$ from those obtained from $2.0-6.0 \mathrm{mg} / \mathrm{mL}$ WSF concentrations. However, the effects of the aqueous fraction of the crude oil were significantly different $(\mathrm{P}<0.01)$ at WSF concentrations of $7.0 \mathrm{mg} / \mathrm{mL}, 8.0 \mathrm{mg} / \mathrm{mL}$ and $9.0 \mathrm{mg} / \mathrm{mL}$ with percentage germination values of $44 \%, 46 \%$ and $29 \%$ respectively. These findings show that the fungal spore could be penetrated by the chemical constituent of the study agent. Previous study found that water-soluble fraction of crude oil could penetrate the tissues and reduced the growth and development of aquatic macrophytes and other water species [10-12]. Hence, this finding agrees with their submissions. The severity of any chemical agent, such as petroleum, dependents on its concentration, the organism physiology and mode of actions [13]. In this study, the effect of the dissolved hydrocarbon fraction could be attributed to any its inherent antifungal components. Thus, such agents could be used to control sporulation of fungal spores.

Table 1. Effect of water soluble fraction of crude oil on spore germination of B.theobromae.

\begin{tabular}{|c|c|c|c|c|c|c|c|c|c|}
\hline & & $2 \mathrm{hrs}$ & & $3 \mathrm{hrs}$ & & $4 \mathrm{hrs}$ & & $5 \mathrm{hrs}$ & \\
\hline WSF(mg/ml) & NSS & NGS & $\% G$ & NGS & $\% \mathrm{G}$ & NGS & $\% G$ & NGS & $\% G$ \\
\hline 0 & 20 & 10 & 50 & 16 & 80 & 18 & 90 & 20 & 100 \\
\hline 1 & 15 & 7 & 47 & 8 & $53 *$ & 10 & $67 *$ & 13 & $87 *$ \\
\hline 2 & 10 & 4 & $40 *$ & 5 & $50 *$ & 6 & $60 *$ & 8 & $80 *$ \\
\hline 3 & 16 & 6 & $38 *$ & 7 & $43^{*}$ & 9 & $56^{*}$ & 11 & $59 *$ \\
\hline 4 & 18 & 6 & $33 *$ & 7 & $39 * *$ & 10 & $55^{*}$ & 10 & $56^{*}$ \\
\hline 5 & 13 & 4 & $30 *$ & 5 & $39 * *$ & 6 & $46^{*}$ & 7 & $54 *$ \\
\hline 6 & 12 & 3 & $25^{* *}$ & 4 & $33 * *$ & 5 & $42 * *$ & 6 & $50 *$ \\
\hline 7 & 25 & 6 & $24 * *$ & 8 & $32 * *$ & 9 & $36^{* *}$ & 11 & $44^{* *}$ \\
\hline 8 & 28 & 5 & $18 * *$ & 7 & $25^{* *}$ & 8 & $29 * *$ & 10 & $36^{* *}$ \\
\hline 9 & 24 & 4 & $17 * *$ & 9 & $21 *$ & 11 & $29 * *$ & 11 & $29 * *$ \\
\hline
\end{tabular}

Key: WSF $=$ Concentration of water soluble fraction of crude oil,

$\mathrm{NSS}=$ Number of spore per $0.2 \mathrm{~mL}$ suspension;

$\mathrm{NGS}=$ Number of germinated spores;

$\% \mathrm{G}=$ Percentage germination;

$* \mathrm{P}<0.05$ and $* * \mathrm{P}<0.01=$ statistically significant mean values $(\mathrm{n}=3)$ compared to control

The effect of the aqueous fraction of the hydrocarbon on the mycelial growth and dry weight after 10 days of incubation are show in Figure 1. From the results, it was observed that the mycelial dry weight remained significantly unchanged $(\mathrm{P}>0.05)$ at the higher concentrations $(4.0-5.0$ $\mathrm{mg} / \mathrm{mL}$ ) after 10 days of incubation (Figure 1). Similarly, the aqueous hydrocarbon fraction was also observed to inhibit the mycelial growth in a concentration dependent pattern. The effect was highest at $9 \mathrm{mg} / \mathrm{mL}(73.0 \%)$ and lowest at 1.0 $\mathrm{mg} / \mathrm{mL}(7 \%)$. The antifungal activities of WSF of hydrocarbon observed in this were relatively higher than those reported for some plant extracts against the same phytopathogens. According to Nweke [14], the aqueous leaf extracts of Cassia alata (L.), Azadirachta indica (A. Juss.), Citrus aurantifolia (Christm. Swingle) and Anacardium occidentale (L.) respectively yielded 44.44\%, 22.22\%, $23.68 \%$ and $5.93 \%$ mycelia growth inhibitions, where were lower than our findings. Similarly, they reported lower inhibitory activities (42.33\%, 29.10\%, 26.72\% and $0 \%$ ) against the spore germination. Comparable activities were reported for other medicinal plants against other phytopathogens [15-17]. Findings from this study were also comparable to the effect of chemical fungicides reported earlier $[18,19]$. Our findings, thus, suggest that water soluble fractions of petroleum hydrocarbon possess constituents that can also prevent the mycelial growth and development of the test fungal pathogen. Previous study had reported that agents with inhibitory effect against sporulation, mycelia growth and development would be potential candidate for fungicide agent [7, 20, 21]. Therefore, water-soluble factions of petroleum hydrocarbon could be used to produce effective fungicide against the test crop pathogens. The significant effect of the chemical agent against the test pathogen, even at relatively low concentrations and short duration, further reduces the risk of residues and bioaccumulation associated with conventional chemicals fungicide in the environment. 


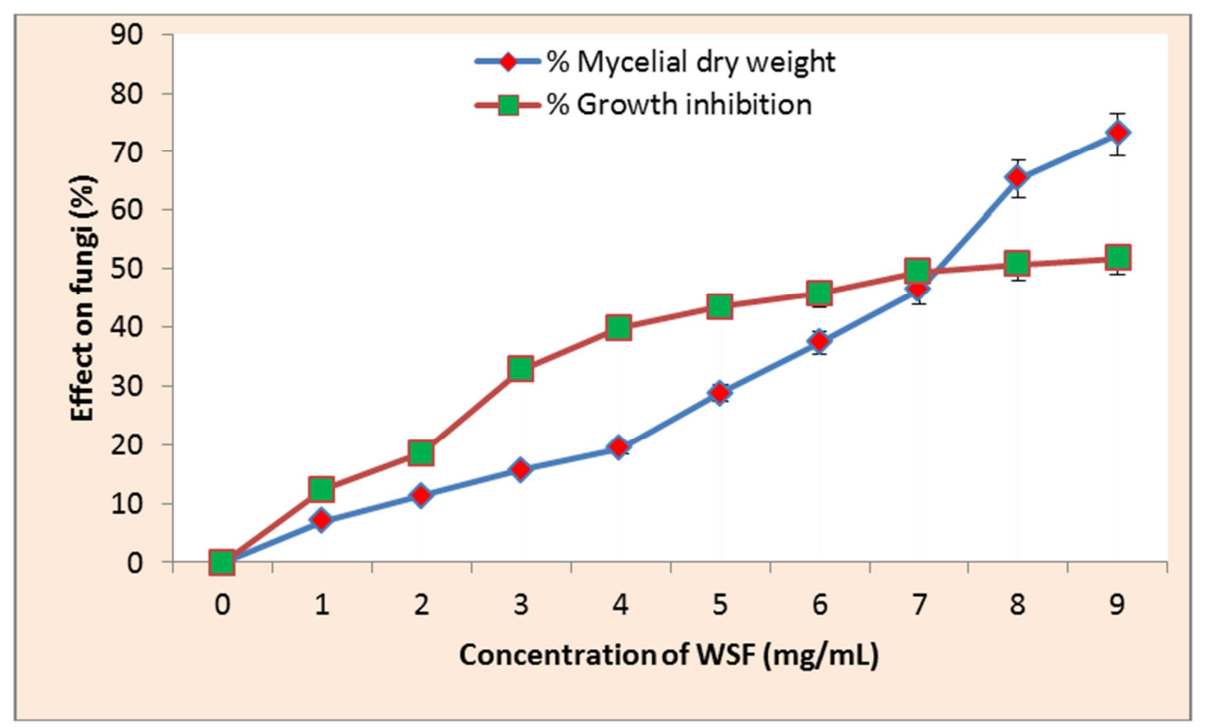

Figure 1. Effect of WSF of crude oilon the growth and dry weight of B. theobromae (Pat.) after 10 days of incubation.

\section{Conclusion}

This study has revealed that aqueous soluble factions of petroleum hydrocarbon possess in vitro antifungal effect against spore germination and mycelial growth of $B$. theobromae (Pat.). The effects were found to be concentration-dependent and significant at $\mathrm{P}<0.01,0.05$ suggesting a possible significant fungicidalaction at relatively high concentrations. The mycelial dry weights of the fungus were not significantly affected at relatively high concentrations of the agent. Although, petroleum hydrocarbons is a well known to posses some toxic components, it is important to suggest that if the actual bioactive chemical constituents of the studied water-soluble fractions are characterized, their known structures can be biosynthesized and exploited as an environmentally friendly biocide with significant efficacy. Hence, the aqueous soluble factions of petroleum hydrocarbon can be further studied (in vitro and in vivo) and possibly exploited as template for biosynthesis of fungicide against $B$. theobromae (Pat.) infection in economic plants. This could probably generate another potential channel for fruitful exploitation of the abundant natural petroleum hydrocarbon resources in the environment.

\section{References}

[1] Domsch, K. H., W. and Anderson, T. H. (2007). Compendium of Soil Fungi. 2nd Edition. Cornell University. England.

[2] Ohene-Mensah G. (2012). Characterization of Botryodiplodia theobromae isolates affecting cocoa, mango, banana and yam in Ghana. A thesis resented to the Department of Biochemistry and Biotechnology, Kwame Nkrumah University of Science and Technology, in Partial fulfillment of requirement of M.Sc. (Hons) Degree in Biotechnology, Ghana. pp. 1-67.

[3] Jones, D. R. and Stove, R. H. (2000). Fungal diseases of banana fruit, pre-harvest disease. In: Diseases of Banana, Abacá and Enset, D. R. Jones (Ed.). CABI Publishing. Wallingford, UK. pp.173-190.

[4] Phipps, P. M. and Porter, D. M. (1998). Collar rot of peanut caused by Lasiodiplodia theobromae. Plant Dis. 1998; 82:1205-1209.

[5] Twumasi, P., Ohene-Mensah, G. and Moses, E. (2014). The rot fungus Botryodiplodia theobromae strains cross infect cocoa, mango, banana and yam with significant tissue damage and economic losses. Afr. J. Agric. Res. 9(6): 613-619.

[6] Syed, R. N., Mansha, N., Khaskheli, M. A., Khanzada, M. A. and Lodhi, A. M. (2014). Chemical control stem end rot of mango caused by of Lasiodiplodia theobromae Pak. J. Phytopathol. 26 (02): 201-206.

[7] Rossman, A. Y., Palm, M. E. and Spielman, L. J. (1997). A literature guide for theidentification ofplant pathogenic fungi. Minnesota, USA, APS Press. 24pp.

[8] Markson, A. A., Amadioha, A. C., Omosun, G., Madunagu, B. E., Udo, S. E and Umana, E. J. (2012). Control of Botryodiplodia theobromae causing Tissue Rot of White Yam (Dioscorea rotundata Poir). Schol. J. Agric. Sci. 2(1):1-7.

[9] SAS. (2002). Statistical Analytical System. User's guide statistics version 91, SAS Institute Inc. Raleigh, N. Y. USA.

[10] Edema, N. E., Okoloko, G. E. and Ogbogidi, M. O. (2007). Physico-chemical characteristics of the water-soluble fraction of Ogini well-head crude oil and the effects on Pistia stratiotes Linn (Water lettuces). American-Eurasian J. Agric. Environ Sci., 2007; 2(6):633-638.

[11] Sadani, M., Movahedian, H.,Faraji, M., Jaberian, B., Hajian, M. and Mehrizi, E. A. (2011). Effects of Physical and Chemical characteristics of water on Toxicity of crude oil water soluble fraction on Daphnia Magna. World Appl. Sci. J. 14 (11):1744-1747.

[12] Bamidele, J. F. and Eshagberi, G. O. (2015). Effects of Water Soluble Fractions of Crude Oil,Diesel Fuel and Gasoline on Salvinia nymphellula (Desv). J. Nat. Sci. Res. 5(14):31-37. 
[13] Overton, E. B., Sharp, W. D. and Roberts, P. (1994). Toxicity of Petroleum. In: BasicEnvironmental Toxicology. Cockerham LG and Shama BS (Eds.). First Edition CRC Press Inc. New York. pp 133-156.

[14] Nweke, F. U. (2015). Effect of some plant leaf extracts on mycelia growth and spore germination of Botryodiplodia theobromae causal organism of yam tuber rot. J. Bio. Agric. and Healthcare. 5(8): 67-71.

[15] Anuagasi, C. L., Onuorah, J. A. and Okigbo, R. N. (2017). Fungal pathogens affecting seedlingsof Gmelina arborea Roxb and Tectona grandis L. F. and effect of three plant extracts. Int. J. Agric. Technol. 13(3): 307-330.

[16] Ekhuemelo, C. and Yaaju, M. D. (2017). Identification and management of fungi associated with crown rot of banana in Makurdi, Benue State, Nigeria. Nig. J. Agric. Food Environ. 13(2):50-55.

[17] Shiriki, D., Ubwa, S. T. and Shambe, T. (2015) Isolation of nine microorganisms from rotten Dioscorea rotundata (White yam) and antimicrobial sensitivity test with five plant pxtracts. Food Nutri. Sci.6: 825-835.

[18] Akinde, S. B., Adeniyi, M. A., Adebunmi, A. A., Oluwajide, O. O. and Ogunnaike, O. O. (2017). Comparative effectiveness of chemical biocides and Acalypha wilkesiana leaf extract against postharvest fungal deteriogens of sweet orange (Citrus sinensis) fruits. Egyptian J. Basic Appl. Sci. 4: $143-152$.

[19] Javaid, A., Shoaib, A. and Akhtar, N. (2008). In vitro chemical control of Botryodiplodia theobromae, the cause of Dying Back disease of mango. Pak. J. Phytopathol. 20(2): 195-199.

[20] Shuping, D. S. S. and Eloff, J. N. (2017). The use of plants to protect plants and food againstfungal pathogens: a Review. Afr. J. Trad. Complement. Alt. Med. 14 (4):120-127.

[21] Anjum M. A, Ahmed, N, Babita, C. H. and Gupta, P. (2016) Plant extracts in post-harvest disease management of fruits and vegetables-A Review. J. Food Process Technol. 7: 592. doi:10.4172/2157-7110.1000592. 